\title{
Cantagalli
}

ESPOSITO, Giuseppe; CONSIGLIO, Silvana. La relazione mística: esperienza e coscienza cristiana di Dio. Itália: Cantagalli, 2006, 280p., ISBN: 888272-281-3.

\section{Ediciones Sigueme}

BOROBIO, Dionisio. El sacramento de la reconciliación penitencial. Salamanca: Ediciones Sigueme, 2011, 430p., ISBN: 978-84-301-1772-7.

\section{Editorial Trotta}

BLANCO, Carlos. El pensamento de la apocalíptica judia: ensayo filosóficoteológico. Madrid: Editorial Trotta, 2013, 226p., ISBN: 978-84-9879-431-1. BOFF, Leonardo. Cristianismo: lo mínimo de lo mínimo. Madrid: Editorial Trotta, 2013, 113p., ISBN: 978-84-9879-443-4.

BOFF, Leonardo. Francisco de Roma y Francisco de Asis: uma nueva primavera en la Iglesia? Madrid: Editorial Trotta, 2013, 117p., ISBN: 978-84-9879-474-8.

BOYARIN, Daniel. Espacios fronterizos: judaismo y cristianismo en la Antigüedad tardia. Madrid: Editorial Trotta, 2013, 419p., ISBN: 97884-9879-433-5. 
GONZÁLEZ FAUS, José Ignácio. Herejías del catolicismo actual. Madrid: Editorial Trotta, 2013, 131p., ISBN: 978-84-9879-423-6.

KÜNG, Hans. Tiene salvación la Iglesia? Madrid: Editorial Trotta, 2013, 199p., ISBN: 978-84-9879-370-3.

LUCIA, José Sols. Cinco lecciones de pensamento social cristiano. Madrid: Editorial Trotta, 2013, 128p., ISBN: 978-84-9879-460-1.

SAN MARTÍN, Javier; SANCHEZ, Juan José. Pensando la religión: homenaje a Manuel Fraijó. Madrid: Editorial Trotta, 2013, 639p., ISBN: 978-849879-442-7.

TILLICH, Paul. Dogmática (lecciones de desde 1925-1927). Madrid: Editorial Trotta, 2013, 419p., ISBN: 978-84-9879-441-0.

TORRES QUEIRUGA, Andrés. Alguien así es el Dios en quien yo creo. Madrid: Editorial Trotta, 2013, 156p., ISBN: 978-84-9879-445-8.

\section{Liturgical Press}

COFFEY, David M. The sacramento of reconciliation. Collegeville, Minnesotta: Liturgical Press, 2001, 189p., ISBN: 978-0-8146-2519-4.

\section{Loyola}

CRÜSEMANN, Frank. Cânon e história social: ensaios sobre o Antigo Testamento. São Paulo: Edições Loyola, 2009, 493p., ISBN: 978-85-1503619-6.

FABER, Eva-Maria. Doutrina católica dos sacramentos. São Paulo: Edições Loyola, 2008, 303p., ISBN: 978-85-15-03495-6.

LENZENWEGER, Josef; STOCKMEIER, Peter; AMON, Karl;ZINHOBLER, Rudolf. História da Igreja Católica. São Paulo: Edições Loyola, 2013, 393p., ISBN: 978-85-15-03040-8.

POTESTÀ, Gian Luca; VIAN, Giovanni. História do cristianismo. São Paulo: Edições Loyola, 2013, 391p., ISBN: 978-85-15-03986-9.

SESBOÜE, Bernard (Org.). História dos dogmas. Tomo 1 (o Deus da salvação). São Paulo: Edições Loyola, 2002, 439p., ISBN: 978-85-15-02038-6.

SESBOÜE, Bernard (Org.). História dos dogmas. Tomo 2 (o homem e sua salvação). São Paulo: Edições Loyola, 2013, 504p., ISBN: 978-85-1502052-2.

SESBOÜE, Bernard (Org.). História dos dogmas. Tomo 3 (os sinais da salvação). São Paulo: Edições Loyola, 2013, 533p., ISBN: 978-85-1502096-6. 
SESBOÜE, Bernard (Org.). História dos dogmas. Tomo 4 (a palavra da salvação). São Paulo: Edições Loyola, 2013, 528p., ISBN: 978-85-15-02232-8.

\section{Paoline}

RAHNER, Karl. La Penitenza dela Chiesa: saggi teologici e storici. Roma: Paoline, 1992, 876p., ISBN: 978-88-215-2487-5.

\section{Paulinas}

BINGEMER, Maria Clara Lucchetti; FELLER, Vitor Galdino. Deus-amor: a graça que habita em nós. São Paulo: Paulinas, 2003, 156p., ISBN: 97885-356-1217-3.

MATOS, Henrique Cristiano José. Nossa história: 500 anos de presença da Igreja Católica no Brasil. Tomo 1. São Paulo: Paulinas, 2001, 319p., ISBN: 978-85-356-0737-6.

MATOS, Henrique Cristiano José. Nossa história: 500 anos de presença da Igreja Católica no Brasil. Tomo 2. São Paulo: Paulinas, 2001, 275p., ISBN: 978-85-356-0898-2.

MATOS, Henrique Cristiano José. Nossa história: 500 anos de presença da Igreja Católica no Brasil. Tomo 3. São Paulo: Paulinas, 2001, 320p., ISBN: 978-85-356-0960-1.

PASSOS, João Décio. Teologia e Outros Saberes: uma introdução ao pensamento teológico. São Paulo: Paulinas, 2011, 203p., ISBN: 978-85356-2589-9.

\section{Paulus}

ALBERICO, Giuseppe (Org.). História dos concílios ecumênicos. São Paulo: Paulus, 1997, 470p., ISBN: 85-349-0040-X.

STONE, Howard W. Depressão e esperança: novas visões para o aconselhamento pastoral. São Paulo: Paulus, 2010, 248p., ISBN: 97885-349-3136-6.

TEMPORELLI, Clara. Maria, mulher de Deus e dos pobres: releitura dos dogmas marianos. São Paulo: Paulus, 2010, 263p., ISBN: 978-85-349-3146-5.

\section{Pontifícia Università Gregoriana}

BARRIOCANAL GÓMEZ, José Luis. La relectura de la tradición del Êxodo en el libro de Amós. Tesi Gregoriana, Serie Teologia 58. Roma: Editrice Pontifícia Università Gregoriana, 2000, 327p., ISBN: 88-7652-852-0. 
MEIATTINI, Giulio. Sentire cum Christo: la teologia dell'esperienza cristiana nell'opera di Hans Urs von Balthasar. Tesi Gregoriana, Serie Teologia 36. Roma: Editrice Pontifícia Università Gregoriana, 1998, 430p., ISBN: 88-7652-783-4.

\section{Santuário}

AZZI, Riolando. A Igreja Católica na formação da sociedade brasileira. Aparecida/SP: Editora Santuário, 2008, 165 p., ISBN: 978-85-369-0130-5.

\section{Sinodal}

ANDIÑACH, Pablo R. O livro do Exxodo: um comentário exegético-teológico. São Leopoldo/RS: Sinodal, 2010, 398p., ISBN: 978-85-628-6528-2. RÖSEL, Martin. Panorama do Antigo Testamento: história, contexto e teologia. São Leopoldo/RS: Sinodal, 2009, 232p., ISBN: 978-85-628-6503-9.

SCHMIDT, Werner H. A fé do Antigo Testamento. São Leopoldo/RS: Sinodal, 2004, 562p., ISBN: 978-85-233-0719-6.

SCHMIDT, Werner H. Introdução ao Antigo Testamento. São Leopoldo/RS: Sinodal, 2013, 395p., ISBN: 978-85-233-0268-9.

WESTERMANN, Claus. Olivro do Gênesis: um comentário exegético-teológico. São Leopoldo/RS: Sinodal, 2013, 407p., ISBN: 978-85-628-6598-5.

\section{Vida Nova}

HOLLADAY, William Lee. Léxico hebraico e aramaico do Antigo Testamento. São Paulo: Vida Nova, 2010, 628p., ISBN: 978-85-275-0437-9.

STUART, Douglas K.; FEE, Gordon D. Manual de exegese bíblica: antigo e novo testamentos. São Paulo: Vida Nova, 2008, 377p., ISBN: 978-85275-0386-0.

\section{Vozes}

BOFF, Leonardo. Vida para além da morte: o presente: seu futuro, sua festa, sua contestação. Petrópolis: Vozes, 2012, 245p., ISBN: 978-85-326-0488-0. LOSSKY, Nicholas; BONIBO, José Míguez; POBEE, John; STRANSKY, Tom F.; et al. Dicionário do Movimento Ecumênico. Petrópolis: Vozes, 2005, 1167p., ISBN: 978-85-326-3141-1.

SCHENEIDER, Theodor (org.). Manual de dogmática. Volume 2. Petrópolis: Vozes, 2009, 576p., ISBN: 978-85-326-2397-3. 